\title{
Why the World Is a Better Place \\ with Stephen King in It: An Evolutionary \\ Perspective
}

The bestselling author Stephen King is famous for his scary stories. He has terrified millions of people and must be directly responsible for countless nightmares and sweat-drenched sleepless nights. I have heard of people who have had to sleep with the lights on for months because of a King story. I have heard of people whose childhood love of clowns curdled into dread because of King. If one were to type up King's literary rap sheet, the section "Incidents of Sleep Disturbances Caused by Stephen King's $I t$ " alone would require many sheaves of paper. Enough, maybe, for a limited print run of a new King novel. And yet, even though King has dispersed dread, anxiety, horror, and fear since the mid-seventies, I'll argue that the world is a better place with him in it.

There's an obvious reason why that claim is true. The world is a better place with King in it because King generates a lot of sheer monetary value-with an annual income of some \$20 million (Watson, 2019), he pays a lot of taxes, and his prolificacy must keep dozens of people employed in the creative industries. Moreover, King and his wife Tabitha are famous for their philanthropy, donating an estimated $\$ 4$ million to charity each year (King, 2017b). That's value. But King also generates another kind of value, one that is harder to measure-literary value, by which I mean the pleasure and insight that people derive from reading his stories. It is this latter kind of value that is my focus here, and I approach the subject from the perspective of evolutionary literary criticism. This particular perspective has two benefits: One, it is lodged in empirical science, which gives the perspective genuine explanatory power (Carroll, 2011). And two, evolutionary literary theory-with its focus on storytelling as an adaptive mechanism - is keenly attuned to the psychological effects and functions of fiction (Boyd, 2009; Carroll, 1995). Indeed, previous King scholarship has tended to disregard the psychological appeals and 
functions of his stories, focusing predominantly on the ideological underpinnings and ramifications of his work (e.g., Dymond, 2013; Hansen, 2017; Hornbeck, 2016) or on his place in the literary-historical or critical landscape (e.g., Birke, 2014; Magistrale, 2013; Strengell, 2005).

While horror is a widely popular and culturally pervasive genre, some critics consider the genre-and King - unworthy of serious attention, typically on aesthetic and/or moral grounds (Smith, 2002). Such dismissals are misguided. The horror genre fulfills an important psychological function as threat simulation (Clasen, 2017). King provides literary threat simulation, but his horror has extraordinarily wide appeal because it is not just about frightening readers. It is also about using threat simulations to probe character, about people's attempts to cope with terrible situations. When an interviewer asked about the "most essential element of a good horror story," King responded: "Character. You've got to love the people ... There is no horror without love and feeling" (Winter, 1990, p. 306). Indeed, character is central to King's fiction, and to his appeal.

King's literary world is one in which evil is real, but so is goodness. His protagonists-compassionate, imaginative, courageous - usually stand a fighting chance against awe-inspiring, supernatural forces of evil. And while King's human characters are seldom wholly good or wholly evil, some characters are more receptive to the forces of evil than others-and some characters, usually the most imaginative ones, are more alert to the forces of evil than others. Imagination, in King's view, is a double-edged sword - a capacity that generates fear and anxiety by producing images of "dark and draggling horrors" (King, 2011b, p. 413), but also a source of pleasure and a force for good. King tends to associate imaginative traits with his protagonists, and frequently pits imaginative protagonists against unimaginative evil. In The Dark Half (King, 1990), King's protagonist, Thad Beaumont, is an imaginative writer whose family is taken hostage by Beaumont's evil twin, George Stark, who has been brought to life by Beaumont's imagination-a dangerously antisocial literary character emerged in the flesh. But the flesh is ephemeral. Stark is slowly decomposing until he is written back into full health, but he himself is unable to create-he needs Beaumont to write for him. Like Stark, King's antagonists tend to be dully self-absorbed, whereas his protagonists are usually highly prosocial and imaginative, if somewhat socially awkward - not unlike King himself. As he said of his childhood in an interview, "I had friends and all that, but I often felt unhappy and different, estranged from other kids my age." He found pleasure in reading and was an imaginative child, but his vivid imagination seems to have been unusually morbid:

An active imagination has always been part of the baggage I've carried with me, and when you're a kid, it can sometimes exact a pretty grueling toll ... [W] hen I was growing up, I'd think a lot of what would happen if my mother died and I were left an orphan ... [W]ith the kind of imagination I had, you couldn't switch off the images once you'd triggered them, so I'd see my mother laid out in a white-silk-lined mahogany coffin with brass handles, her dead face blank and waxen; I'd hear the organ dirges in the background; and then I'd see myself being dragged off to some Dickensian workhouse by a terrible old lady in black (Norden, 1988, p. 40). 
To the terror and delight of millions of readers across the planet, King has managed to convert his disposition for imaginatively probing the darkest possibilities of the world into a lucrative creative pursuit. His horror stories resonate with those millions of readers because King is uncommonly good at creating immersive imaginative worlds that look very much like our world, but in which vividly depicted and intuitively compelling supernatural forces of good and evil are afoot. Those forces collaborate with and work through fictional characters, whose motives-good or evil-King probes with real understanding of the complexities of human nature. King is not sadistic; he likes to scare readers, but he does so through compassionate depictions of vulnerable characters in confrontation with terrifying forces. This allows King to provide psychological and social insight and prompts for moral calibration by satisfying an evolved appetite for vicarious experience with threat scenarios. And while King is famous for his vivid depictions of horrifying evil, I maintain that his stories are, in fact, a force for good.

\section{The Divided Reception of Stephen King}

King enjoys massive popularity and continues to wield immense pop-cultural influence. He has published more than 60 novels, in addition to some 200 short stories and several non-fiction books. By one estimate, he has sold 350 million books. Many of his stories have been adapted for the screen-some of them to great critical acclaim (e.g., Darabont's The Shawshank Redemption [1994]), and others to almost universal derision (e.g., King's own Maximum Overdrive [1986]). Several King creations have entered popular culture and are instantaneously recognizable even to people who have never read any of his works, such as telekinetic Carrie, the haunted Overlook Hotel, or Pennywise the Dancing Clown. There are King fan clubs, there's King merchandise (from Carrie t-shirts to Pennywise plush toys), and there are King quiz books to keep King fans occupied at get-togethers (e.g., Spignesi, 1990). There are anecdotes of deranged fans violating King's privacy (Lant, 1997). Indeed, anybody who has read King's 1987 novel Misery (2011a) must have wondered about the autobiographical element. In this novel, bestselling author Paul Sheldon is held captive by his self-proclaimed "number one fan," Annie Wilkes, who forces him to resurrect the heroine of the bodice-ripper romance series for which Sheldon is famous, but which he has left behind to pursue more "serious" fiction. And although it's too easy to read Misery as King's hate-mail to his fans-Sheldon is clearly not a clone of King - the novel is supposedly inspired by King's experiences with rabid fans (Beahm, 1998).

King's wide appeal is undoubtedly due chiefly to the literary qualities of the stories he writes - the complex characters, the vividly depicted images of horror, the verisimilitude of his imaginative worlds, his suspenseful plots, and the accessibility of his language. Those are the recurrent qualities mentioned by King enthusiasts on such fora as Goodreads. King's public persona and his life-story add to his appeal. He seems like an easy-going, down-to-earth guy, despite his massive wealth. 
He does interviews on national television wearing well-worn blue jeans and casual t-shirts. He jokes about being a bumpkin from Maine. He talks plainly and candidly about growing up with an overworked single mother, struggling financially during college and up until he sold the paperback rights to his 1974 debut novel, Carrie (1999), and about a life-long dance with the demons of substance abuse (King, 2012). He loves dogs and thinks farts are funny. And his rags-to-riches story is authentic and appealing (Magistrale, 2013; Rogak, 2009). There's a lot to like here, and King's easy-going, good-natured yet compulsively morbid personality bleeds into his stories.

Alongside the hard-core King fans are diehard critics. Among them, the ghost of the late literary scholar Harold Bloom stands out as the most vocal and influential. Bloom edited a volume of critical writings about King's work and said in his brief introduction to the volume that "I find King very hard to read." (Why he would edit such a collection remains a mystery.) He went on to say that "the triumph of the genial King is a large emblem of the failures of American education" (Bloom, 2007, p. 2). While Bloom granted to King a certain "decency," a certain "social benignity" (p. 3) - presumably referring to King's acts of charity as well as to the "redeeming social values" (p. 2) that Bloom found in some of King's stories-he was unequivocal in his scorn. When in 2003 the National Book Foundation awarded King the prestigious Medal for Contribution to American Letters, Bloom wrote an angry op-ed, saying that the award represented "another low in the shocking process of dumbing down our cultural life." He added that King "is an immensely inadequate writer on a sentence-by-sentence, paragraph-by-paragraph, book-by-book basis" (Bloom, 2003).

King scholars have puzzled over this divided reception. How can a writer inspire almost-religious devotion in some and tooth-grinding scorn in others? While they have not yet adequately answered that question, they have identified reasons why some critics dismiss King (Smith, 2002) — the most prominent one being genre. Horror, the genre for which King is best known, continues to struggle with a bad reputation. The genre is, at least in some circles, conceived as a psychologically shallow, aesthetically uninteresting, and maybe even morally problematic mode of writing (Gutiérrez, 2017; Jancovich, 1992). And while there is a lot of bad horror out there, there is also horror that has real merit-horror that is psychologically probing, aesthetically ambitious, and morally nuanced (Clasen, 2017).

The best of King's horror has those qualities. King uses the elements of horror, whether naturalistic or supernatural, not just for their own sake, but to examine people and the world in which they find themselves. He has used pretty much every Gothic and horror trope there is: haunted houses, psycho killers, ghosts, vampires, zombies, werewolves, demons, evil extraterrestrials, possessed dolls, abominations from other dimensions, terrors from the grave, you name it. Those tropes carry intrinsic interest and value for King, but they are also used to qualify and deepen his investigations of human motivations and social structures. In The Shining (King, 2011c), for example, he casts his eye on the main character, Jack Torrance's, futile struggles against his inner demons and his psychological freefall into homicidal madness. By situating this drama in a hotel haunted by external demons that fuel 
Torrance's inner ones, King elevates a social realist drama of thwarted ambition and pathological family relationships to an imaginatively and symbolically explosive scenario of horror (Clasen, 2017). He uses the trope of the haunted hotel with a sordid past to suggest that evil deeds leave lingering supernatural traces in the world, just as they leave lingering psychological traces. Conversely, he brings the horror tropes to life by situating them within a believable imaginative world that resembles the empirical one in most respects. As King himself puts it, he is "not merely dealing with the surreal and the fantastic but, more importantly, using the surreal and fantastic to examine the motivations of people and the society and institutions they create" (quoted in Smith, 2002, p. 338).

King says that "the art of story-fiction" is "one of the vital ways in which we try to make sense of our lives, and the often terrible world we see around us" (2010, p. 365). This functional proposal aligns with evolutionary theories about the adaptive functions of fiction, in particular the empirically supported hypothesis that fiction provides motivational orientation (Carroll, 2012). We use fiction to make sense of ourselves and the world. King, through his stories, thus provides to readers the kind of "emotionally saturated images of the world and of human experience" (Carroll, 2006, p. 42) for which we have an evolved desire, because such images help us navigate the uniquely complex social and psychological worlds in which we humans find ourselves.

\section{The Uses of King's Horror: An Evolutionary Perspective}

The imaginative virtual worlds into which King invites his readers are usually scary, and King evidently enjoys scaring his readers. He is temperamentally drawn to the horror genre. As he said in a 1985 interview, “There are a lot of people who are convinced that, as soon as I've made enough money, I will just leave this silly bullshit behind me and go on to write Brideshead Revisited and spy novels and things like that. I don't know why people think that. This is all I've ever wanted to write" (Winter, 1990, p. 305). And as he said in another interview, "I don't think there's anything sweeter on God's green earth than scaring the living shit out of people." He went on to explain that:

if somebody wakes up screaming because of what I wrote, I'm delighted. If he merely tosses his cookies, it's still a victory but on a lesser scale. I suppose the ultimate triumph would be to have somebody drop dead of a heart attack, literally scared to death. I'd say, "Gee, that's a shame," and I'd mean it, but part of me would be thinking, Jesus, that really worked! (Norden, 1988, p. 40).

King's readers, in turn, enjoy being scared. As one Goodreads user wrote of Pet 
While horror is a pervasive pop-cultural phenomenon, not all readers enjoy horror. In a previous study sampling the American population (Clasen, KjeldgaardChristiansen, \& Johnson, 2018), we found that more than half claim to enjoy horror media. Slightly more than a quarter say they don't like horror. And the remaining respondents are indecisive, claiming neither a preference for or against horror. This distribution of people on a scale ranging from avoidance of horror to liking of horror, which results at least partly from personality differences among media users (Clasen et al., 2018), may help explain the divided reception of King. Some readers simply don't enjoy being scared by fiction. They stay away from anything labeled horror, and their understanding of what the genre is may be impoverished. For such readers, horror as a genre label may conjure up images of masked killers chasing buxom teenage scream queens. But as I hope to show in this chapter (and have argued elsewhere, e.g., Clasen, 2017), there is more to horror than masked killers and scream queens.

The widespread desire to be frightened by fiction is explicable in terms of threat simulation. Horror is a means for readers to become immersed in frightening fictional worlds - virtual worlds in which they can empathize with vulnerable characters who confront terrifying forces of evil—and so to expand their experience. They learn what it feels like to be hunted prey, to be assaulted by dangerous forces. They vicariously live through worst-case scenarios (Morin, Acerbi, \& Sobchuk, 2019). That kind of threat simulation is pleasurable to most people because it satisfies an adaptive desire for expanding experience through imaginative simulation (Clasen et al., 2018). The imaginative structures provided in King stories usually offer dark simulated experience-simulations that take us to the fringes of human experience, into realms of darkness and horror and despair.

King, then, like other accomplished horror writers, makes his living by creating imaginative virtual worlds in which his readers can playfully engage in threat simulation. However, his exceptionally wide appeal suggests that he offers readers something more than the literary equivalent of yelling "BOO!" His horror allows him to provide psychological and social insight into the extremes of experience, and the compassion that saturates his stories appeals to many readers, perhaps because it makes the darkness into which he delves bearable by shooting it through with light. Some of King's stories are bleak, in particular the books written early in his career under the pen name Richard Bachman and in a state of "low rage and simmering despair" (King, 1996, p. vi). But while King can be bleak, and gleefully morbid, and irreverently gross, he is never nihilistic, never sadistic.

\section{Charting the Dark Corners of the Psychological World: Pet Sematary}

Consider Pet Sematary (King, 2011b), King's notoriously scary 1983 novel about a family that loses first a cat and then a toddler to the highway that runs past their new house. The protagonist, Louis, learns from his elderly neighbor, Jud, about an ancient Native American burial ground deep in the woods behind his home. Whatever one buries there comes back from the grave, but it comes back "a little 
dead. A little strange" (p. 181). When the family cat is killed by a vehicle, Louis hides the death from his daughter to protect her from the shock of mortality. He also hides the death from his wife, Rachel, who was traumatized by the horrible demise of her sister when she was a child, and now lives in denial of mortality. Goaded by Jud, who is compelled by a supernatural force of evil, Louis buries the cat in the Native American burial ground. The cat comes back, but it's weird and mean. It kills and mangles a lot of birds and mice. Louis discreetly disposes of the corpses, thinking to himself that he is to blame-that he has "bought them"-by having taken advantage of the supernatural burial ground. Shortly thereafter two-year-old Gage is hit and killed by a truck. Louis, devastated by grief, decides to exhume his son and re-bury him in the Native American burial ground. Gage, too, returns from the grave, but he's now evil. Resurrected Gage kills both Jud and his own mother. Louis, now completely shattered by horror and sorrow, takes his wife's corpse to the Native American burial ground. She, too, returns. The end.

Even though this scenario is wildly implausible, there is real emotional depth here, real psychological insight. King gives us an imaginative world that is darkly re-enchanted, one in which magical forces and supernatural agents are real. There is a peculiar and ambivalent appeal in envisioning such imaginative worlds. The human mind evolved to helplessly, promiscuously, project magical forces and supernatural agents into the world (Atran \& Norenzayan, 2004; Boyer, 2001). Science has struggled for centuries to banish those forces from the world, to disenchant the world, but science is up against deep-seated intuitions. Most people, despite rational convictions, occasionally intuit supernatural forces at work. And to most people, the intuition that such forces exist is both comforting and terrifying, suggesting some ulterior meaning to the universe and the individual life but also suggesting the existence of frightening supernatural agents. King exploits such intuitions by describing an imaginative world in which the forces are real. Doing so allows him to take his investigation of the depths of grief and horror to a level beyond that which a realistic depiction of the loss of a child would allow.

King takes on a big topic, one that most people don't much enjoy thinking about, and creates an absorbing, deeply disturbing, but ultimately life-affirming story around it. That big topic is death. Death is a prominent theme in literature because it is a prominent theme in life. It is vast and shrouded in mystery, inescapable and unknowable, terrifying yet fascinating. Death excites the imagination, "goading people into attempting to imagine the end of all imagination, and compelling them to wonder about the meaning and value of a life that seems a mere flicker of conscious experience isolated within an unimaginable infinity of nothingness" (Carroll, 2019, p. 137). In Pet Sematary, death is not the end, but it should be. The dread of undeath makes the value of life stand out. Jud knows he should not bury anything in the Native American burial ground, and that he should not encourage his friend to do so. But the force of evil works on him, compels him. "That place ... all at once it gets hold of you," says Jud in an attempt to explain why he told Louis about the burial ground. "You make up the sweetest-smelling reasons in the world" (King, 2011 b, p. 183). Later in the story, when Gage is dead and Jud suspects that Louis may be contemplating the interment of his son in the Native American burial ground, 
he tries to warn Louis: "It's an evil, curdled place, and I had no business taking you up there to bury that cat. I know that now" (p. 307). Too late. Louis, weakened by grief and unable to accept the finality of death, gives in to the lure of the place and sets out on the course that ends with him toppling into an abyss of horror.

In the most disturbing scene of the novel, Louis breaks into a cemetery at night to exhume his son. King lets the reader into the thoughts and emotions of Louis, with whom the story is focalized. We do get a brief description of Gage's corpsewhich looks like "a badly made doll" with "damp moss" growing on its face (p. 387)_but the focus is on Louis's inner turmoil, his rage and grief and deep doubts. When Louis has opened the coffin and shines his flashlight into it, "a deep horror that was very nearly awe stole over him-it was the sort of feeling usually reserved for the worst nightmares, the ones you can barely remember upon awakening" (p. 386). Louis then proceeds to lift the corpse out of the grave:

Somehow, panting, his stomach spasming from the smell and from the boneless loose feel of his son's miserably smashed body, Louis wrestled the body out of the coffin, then out of the grave. At last he sat on the verge of the grave with the body in his lap, his feet dangling in the hole, his mouth drawn down in a trembling bow of horror and pity and sorrow (p. 388).

The image is vivid and resonant. King paints the scene in uncomplicated, colloquial language and provides enough sensory detail for us to mentally simulate the scene, including the stench of decomposition and the tactile reality of a broken corpse. We see before us Louis's “dangling" feet, we see him giving in to powerful emotion. We are being put right by the grave with Louis, and we are invited to share his pain, his grief. Since people respond to literary characters in much the same way as they respond to real people (Mar \& Oatley, 2008), our empathy is mobilized and our emotions powerfully roused by this description of Louis's response. Moreover, the death of an innocent child is a potent motif, for good evolutionary reasons-humans evolved to value and feel protective of children, who are more vulnerable to danger than are adults. Even the fictional death of a fictional child can stir our sympathy and grief. The "magnitude of the loss [of a child] evokes a special pathos," says Carroll, because what is lost when a child dies "is the whole potential future life of the child" (Carroll, 2019, p. 148). King skillfully capitalizes on this in a short chapter that comes after Gage's funeral. This chapter begins: "But none of those things happened" (King, 2011b, p. 309). The chapter goes on to detail, in short order, how Gage narrowly avoids being hit by the truck, how he grows up to become a university student and an avid swimmer and has a full and fulfilling life. And then Louis “woke up in the cold dead light of a rainy seven o' clock, clutching his pillow in his arms ... the pillow was wet with his tears" (p. 312). It was just a dream. This gutwrenching chapter brings home the "magnitude of the loss" by first giving the reader a sense of relief and then ramming home the terrible diegetic reality. Gage did die. He did not grow up, did not attend Johns Hopkins, never learned to swim.

King clearly wants us to feel what Louis feels. He has also been careful to depict Gage as a lively, trusting, likeable toddler and to depict the loving bond between 
father and son. One long passage describes father and son flying a kite. Louis gets 330 the kite into the air and hands Gage the kite-string:

"Gage flyne it?" Gage said ... He pulled the string experimentally; the kite nodded in the windy sky ... Louis and his son laughed together. Gage reached out his free hand, groping, and Louis took it in his own. They stood together that way in the middle of Mrs. Vinton's field, looking up at the [kite].

It was a moment with his son that Louis never forgot. As he had gone up and into the kite as a child himself [imagining himself flying], he now found himself going into Gage, his son. He felt himself shrink until he was within Gage's tiny house, looking out of the windows that were his eyes-looking out at a world that was so huge and bright ... where the kite soared miles above him, the string drumming in his fist like a live thing as the wind blew around him, tumbling his hair.

"Kite flyne!" Gage cried out to his father, and Louis put his arm around Gage's shoulders and kissed the boy's cheek, in which the wind had bloomed like a wild rose.

"I love you, Gage," he said-it was between the two of them, and that was all right.

And Gage, who now had less than two months to live, laughed shrilly and joyously. "Kite flyne! Kite flyne, Daddy!” (pp. 248-249).

The scene captures the emotional depth and power of a healthy father-son relationship in general and of Louis's affectionate bond with his son in particular. It also captures something of the evanescence of life. The stark subordinate clause toward the end of the passage - "who now had less than two months to live"- - serves as a brutal memento mori to the reader who, absorbed in the moving depiction of these characters, had perhaps forgotten that they were reading a horror novel that thematizes the fragility of life and the tragedy, but also inevitability and naturalness, of death. The scene, moreover, captures the transformation of the pure pleasures of childhood into the mature, but more complicated, joys of parenthood. A child can be content with (and may be unable to transcend) its own perspective. A responsible parent, however, is always invested in several perspectives-their own, that of a coparent, those of offspring. Here, in this passage, Louis inhabits his own and Gage's perspectives and shares in Gage's childish joy at the flying kite. As the story progresses, however, and Louis sinks into horror and grief, he forgets all but his own perspective.

King's sympathetic depiction of Louis is nuanced by a critical perspective on his actions. We share Louis's perspective visually and emotionally, but not necessarily morally. As the plot unfolds, Louis's actions become increasingly morally problematic-culminating, of course, with the resurrection of his son. In one scene-not shocking, like the exhumation scene, but symptomatic of Louis's psychological decline-Louis, his wife Rachel, his friend Jud, and his colleague Steve are gathered for a meal after Gage's funeral service. Rachel has a breakdown, "sobbing into her hands":

There was a queer moment then. There were crossing lines of tension then, and they all seemed to focus on Louis ... Even the waitress felt those converging lines of awareness. He saw her pause at a table near the back where she was laying placemats and silver. For a moment Louis was puzzled, and then he understood: They were waiting for him to comfort his wife.

He couldn't do it. He wanted to do it. He understood it was his responsibility to do it. All the same, he couldn't. It was the cat that got in his way ... The fucking cat ... with his 
ripped mice and the birds he had grounded forever. When he found them, Louis cleaned up the messes promptly, with no complaint or comment ... He had, after all, bought them. But had he bought this? (pp. 270-271).

Louis is so wrapped up in his own grief, and his aimless rage at the unfairness of Gage's death ("had he bought this?"), that he finds himself unable to comfort his wife. He suddenly becomes aware of the others' perspectives, the "lines of awareness" that converge on him, but he is locked into his own concerns. "After a moment ... Steve put an arm around [Rachel] and hugged her gently. His eyes on Louis's were reproachful and angry" (p. 271). It's a painful scene. The reader is invited to share Louis's perspective, but also Rachel's, and Steve's. We understand Louis's behavior, but also condemn it. This scene-which is the kind of scene I have in mind when I say that King uses horror tropes to conduct serious and sensitive investigations of psychology and sociality — signals Louis's self-absorption, which, together with his unwillingness to accept the finality of death, becomes his tragic flaw. The flaw eventually leads to his fatal and immoral decision to resurrect his son. That selfish action serves only to counteract his own grief. It is depicted as unnatural and wrong, and it unleashes a horror that causes the death of both Jud and Rachel and also the complete mental unravelling of Louis. As Douglas Winter writes, "The death of a child is the ultimate horror of every parent, an outrage against humanity; and the reanimated Gage is precisely that horror made flesh, savaging and literally eating away at his mourning family" (1984, p. 134).

Pet Sematary allows the reader to vicariously feel the near-insane grief of a bereaved parent, to probe the disturbing question of "just how much horror the human mind can stand and still maintain a wakeful, staring, unrelenting sanity" (King, 2011b, p. 255). It prompts the reader to reflect on death and the value of life-not on an abstract level, but through emotional engagement with vividly drawn characters who find themselves confronted with a truly horrifying situation. The responsive reader participates imaginatively in this situation, but also stands back from it and evaluates it and the characters' behavior. The pay-off of reading a novel like Pet Sematary, then, is not just about the pleasure of being absorbed in an imaginatively and emotionally stimulating story populated by interesting characters. That pleasure is real and valuable. But the pay-off is also about "deepening and widening one's emotional experience," in the horror writer Peter Straub's words (quoted in Clasen, 2009, p. 40), about coming face to face with a nightmarish evocation of death, embodied in the reanimated corpses, and about becoming sensitized to the value and fragility of life, and about gaining insight into painful but important psychological and social dynamics. Nobody goes through life without pain and loss. Fiction that seriously explores the depths of pain and loss steels us for that.

\section{Moral Calibration: Agonistic Structure in It}

Fiction has the capacity for letting us vicariously live through scenarios that would, in real life, be unattractive (like losing a child) or even impossible (like resurrecting a child), thus widening and qualifying our experience and ability to cope. Speculative 
fiction-horror, fantasy, and science fiction-deals in imaginative worlds that depart from the empirical one, but such fiction still tends to aspire to psychological realism, which is how it can teach us about the qualities of experience. Fiction may also have the capacity for improving social cognition by "[augmenting] our capacity for empathy and social inference” (Mar \& Oatley, 2008, p. 173). It does so by letting us adopt the perspectives of fictional characters and by giving us insight into their mental processes. Moreover, since fiction typically has a moral structure-expressed perhaps most clearly in agonistic structure, the distribution of characters along a moral continuum from evil to good - it can tweak the reader's moral compass (usually toward the pole of prosociality, cf. Carroll, Gottschall, Johnson, \& Kruger, 2012; Johnson, 2012) and help them assign weight and value to behavioral alternatives.

Consider King's It (King, 2017a), perhaps his most famous novel. This massive 1986 book depicts a small group of friends in the fictional town of Derry, Maine, in their attempt to defeat an ancient and shape-shifting force of evil that awakens every 27 years or so to feed on the flesh and fear and faith of the citizens of Derry, and to infect them with its evil. The good guys - a rag-tag band of kids who call themselves the Losers' Club - take up the fight with this force of evil and with its human collaborators. They manage to momentarily defeat the evil force, but it returns 27 years later. The now-adult protagonists, most of whom have left Derry, must return for a final battle against It. They manage, through their combined efforts, to vanquish It.

It is a sprawling and famously frightening novel, a wide-ranging depiction of the terror and awe of childhood, the magic of friendships, the wonders of imagination, the horrors of history (Mercer, 2019), and the dark forces that hide in the sewer system under Derry and deep within human nature. The central conflict in It-man versus monster-reflects an ancient struggle, one that predates modern humans (Clasen, 2012). Our mammalian ancestors have for millions of years been preyed upon by hungry, fanged animals roaming in the dark (Hart \& Sussman, 2009). The idea of being hunted by a hungry monster still carries salience and resonance beyond reason. The monster of $I t$ is a predator, but it is more than that. It has a supernatural ability to adopt a shape that mirrors the deepest fears of its prey, and it is able to manipulate its prey's perception of reality. Despite the monster's extraterrestrial origin, it has found Earth very hospitable to its needs:

It had discovered a depth of imagination here that was almost new, almost of concern. This quality of imagination made the food very rich. Its teeth rent flesh gone stiff with exotic terrors and voluptuous fears: they dreamed of nightbeasts and moving muds; against their will they contemplated endless gulphs (King, 2017a, p. 1220).

It targets children in particular, because King's children are more perceptive, openminded, and imaginative than adults (Alegre, 2001). Their fears are "simpler and usually more powerful" than adults' fears (King, 2017a, p. 1232). Children are able to accept the impossible, King suggests. They are able to accept the reality of a shape-shifting monster, which makes them more vulnerable to the monster. However, as the protagonists discover, their faith can also be weaponized. They are 
able to fight back when they believe that their weapons, such as home-made silver bullets, are effective against the monster.

One memorable scene depicts one of the Losers-11-year-old Eddie Kaspbrakcoming face to face with one of the monster's embodiments. Eddie is investigating an abandoned house, thinking about his fear of hobos. Eddie suffers from hypochondria, instilled by his domineering mother, and is terrified of infection. Suddenly, he is assaulted by what appears to be a hobo leper:

The skin of its forehead was split open. White bone, coated with a membrane of yellow mucusy stuff, peered through like the lens of a bleary searchlight. The nose was a bridge of raw gristle above two red flaring channels. One eye was a gleeful blue. The other socket was filled with a mass of spongy brown-black tissue. The leper's lower lips sagged like liver. It had no upper lip at all; its teeth poked out in a sneering ring (p. 376).

This detailed depiction of Eddie's nightmare monster-helpfully peppered with similes that facilitate visualization ("like the lens of a bleary searchlight"; "sagged like liver")—exploits an evolved fear of contagion. Humans are biologically disposed to respond with aversion to cues of infection (Tybur, Lieberman, Kurzban, \& DeScioli, 2013), and King provides plenty such cues here, again using unassuming and colloquial language ("yellow mucusy stuff"). More than a zombie-like abomination, however, this particular monster is an externalization of Eddie's fear, a horror image that reflects the psyche of a psychologically abused boy, and thus has a narrative function beyond grossing the reader out.

Eddie and the other kids in the Losers' Club share traits with protagonists throughout literary history. They are keenly attuned to other people, considerate of their needs, and respectful of their perspectives. They are self-sacrificing and prosocial. They are also socially awkward and slightly at odds with society. Bill has a heavy stutter that impedes social interaction and makes him feel insecure. Ben is overweight and friendless. Mike is an African-American and the target of racist abuse. Richie is a wisecracking misfit. Stan is a geeky Jew with a passion for birdwatching. Beverly is a social outcast with an abusive father. This motley crew bands together and finds great pleasure in collaborative, constructive pursuits such as building a dam and an underground clubhouse in the Barrens, the secluded area in which they play. They are also united in being "extraordinarily imaginative" (King, 2017a, p. 1232). Their imagination gets them into trouble—by making them particularly vulnerable to It—but also helps them defeat evil. Here, again, King depicts the imagination as a double-edged sword.

The Losers' power to vanquish the evil force comes not just from their healthy imaginations, King suggests. It comes from the strength of their bonds, from their being a strongly bonded group with prosocial values even toward out-group individuals. In one scene, the Losers are bonding over a game of Monopoly. One of their parents observes as the kids "[roar] with laugher" at an inappropriate joke: "There was a feeling in the air, like static electricity, only somehow much more powerful, much more scary. She felt that if she touched any of them, she would receive a walloping shock" (pp. 1029-1030). King here depicts the social bonds between the children as an almost-physical phenomenon, a power that frightens the parent. 
Similarly, the force of evil intuits that the children's togetherness is their primary power. It looks for a "wedge to drive among them, splitting them apart and destroying any chance of concerted action" (p. 955) —not just because of their aggregated strength, but because of the emergent supernatural or quasi-supernatural force that results from their bond. By elevating the bonds of friendship to an almostsupernatural or spiritual force-conceptualized here, colloquially, as a kind of electricity-King satisfies an evolved tendency to see supernatural or spiritual forces as real agencies.

In contrast to the prosocial protagonists stands the evil force, which finds nourishment in people's fear and suffering. It also eats children. That's about as evil as it gets. This supernatural agent is selfish and sadistic. It recruits people who share its antisocial orientation. In King's stories, external forces of evil often work through human characters by appealing to their antisocial motives. A signal instance of such a recruit is the minor antagonist Patrick Hockstetter, a 12-year-old who becomes a willing tool for It. One chilling chapter takes us into his head. We learn that Hockstetter "could not remember a time when he had believed that other peopleany other living creatures, for that matter-were "real"" (p. 995). His pathological lack of empathy sets him in stark contrast to the Losers. So does his complete lack of artistic inclination, his lack of interest in imaginative activities. At one point, his mother asks about his school day: "Patrick said it was all right and showed her his drawing of a house and a tree. His paper was covered with looping meaningless scribbles made with black and brown crayon ... Patrick brought home the same looping scrawls of black and brown every day. Sometimes he said it was a turkey, sometimes a Christmas tree, sometimes a boy" (p. 998).

In this chapter, we also learn of Hockstetter's dislike of his baby brother, Avery, who causes him minor discomfort - meals are late, Avery cries in the night, and so on. Hockstetter goes into Avery's room, where the infant is sleeping, and presses Avery's face into the pillow. When the noisome baby is dead, Hockstetter goes to the kitchen and gets himself a "plate of cookies and ... a glass of milk" (p. 998). Apart from a transitory feeling of excitement, he registers no strong emotion after the infanticide. No regret, no grief, no horror-not even sadness. He is just relieved, eventually, to find that his meals once again arrive on time. His selfishness is pathological, and he serves as a human analogue to the inhuman force of evil that terrorizes the protagonists.

This distribution of protagonists vs. antagonists on a prosocial-to-antisocial scale is no mere literary convention, but a reflection of evolved human social motives (Carroll et al., 2012). We tend to see prosociality as good and selfishness as bad; indeed, evil in popular culture tends to be characterized as selfish (KjeldgaardChristiansen, 2016). Empirical studies have shown that prosociality is universally seen as morally desirable (Curry, Mullins, \& Whitehouse, 2019). The reason is that we are an ultra-social species that depends on functioning social structures for psychological well-being and biological fitness. Prosocial individuals make up the fabric of such structures; antisocial ones endanger it. In the real world, however, most people harbor prosocial as well as antisocial motives, and we all feel the conflict of such competing motives occasionally. In fiction, the motives are often artificially 
crystallized in morally polarized characters (Carroll et al., 2012). It seems that one of the functions of fiction is to tip the scales a bit and orient us toward prosociality at the expense of selfishness. It does so by mobilizing our admiration at prosocial characters and our disgust at antisocial ones-even supernatural antagonists like It. Indeed, the novel epitomizes King's talent for embodying such abstractions as prosociality and antisociality in vivid and engaging characters.

\section{The Value of King and Directions for Future Research}

Stephen King's popularity as a writer of scary stories makes sense from an evolutionary perspective. By constructing immersive stories populated by engaging characters in terrible situations, he provides an entertaining yet instructive experience to his readers. King thus caters to an evolved desire for imaginative experience with threat scenarios, and to an evolved desire for vicarious insight into psychological and social dynamics. A reader absorbed in $I t$ is likely to come away not just with a sense of horrified delight at having been immersed in a compelling but frightening virtual world of friendship, horror, loss, and death, but also with an admiration for the imaginativeness and prosociality that allow the Losers' Club to prevail and with disgust for the dominance-seeking bullies who torment the Losers. Indeed, empirical research has demonstrated that our values are subtly shaped by the fictional stories that we consume (Johnson, 2012; Gottschall, 2012). Norm transmission seems to be a chief function of fiction, and the norms transmitted by King's stories are invariably prosocial.

King, then, does a lot more than "keep the publishing world afloat," in Bloom's dismissive phrase (2003). King's best stories do good things in the world. Clearly, Carrie didn't spell an end to bullying. The Shining didn't abolish parental abuse. And Pet Sematary didn't put an end to pathological coping with offspring loss. All the same, those novels, and other King stories, have done more than provide hairraising entertainment for their readers. They have helped people understand the dark forces that roam the psychological as well as the socio-moral world. They have done so through their powerfully evocative depictions of "ordinary people in extraordinary situations" (King, 2010, p. 365)—of protagonists struggling with social exclusion, destructive ambition, soul-crushing loss, and terrifying forces of evil.

I hope to have demonstrated here that an evolutionary perspective can put into focus the value of King's oeuvre. Even though evolutionary literary study has shown its explanatory and interpretive value (Carroll, 2018), King has largely escaped the attention of evolutionary critics. Indeed, "despite being one of the most widely read authors of all time, King is woefully understudied" (Cowan, 2018). There is plenty of work left to do for evolutionarily and quantitatively oriented scholars. Future research might investigate individual King stories from an evolutionary perspective, or perform systematic studies of agonistic structure in King's works. It might take advantage of quantitative methods for hypothesis testing. To give just two examples, empirically minded scholars might investigate the psychological, behavioral, and 
moral effects of King's stories in controlled experiments. And they might use machine-assisted data analysis of publicly available reader responses (such as the user-generated reviews on Goodreads) to achieve a better understanding of what it is about King's stories that readers enjoy. Such research would help us understand not just why King is popular, but what the effects of his stories are, and thus provide evidence for or against my claim that the world is a better place with Stephen King in it.

\section{References}

Alegre, S. M. (2001). Nightmares of childhood: The child and the monster in four novels by Stephen King. Atlantis, 23(1), 105-114. https://www.jstor.org/stable/41055012

Atran, S., \& Norenzayan, A. (2004). Religion's evolutionary landscape: Counterintuition, commitment, compassion, communion. Behavioral and Brain Sciences, 27(6), 713-730. https://doi. org/10.1017/S0140525X04000172

Beahm, G. (1998). Stephen King: America's best-loved boogeyman. Kansas City, MO: Andrews McMeel.

Birke, D. (2014). Challenging the divide? Stephen King and the problem of 'popular culture'. The Journal of Popular Culture, 47(3), 520-536. https://doi.org/10.1111/jpcu.12143

Bloom, H. (2003, September 24). Dumbing down American readers. The Boston Globe. Retrieved from http://archive.boston.com/news/globe/editorial_opinion/oped/articles/2003/09/24/ dumbing_down_american_readers/

Bloom, H. (Ed.). (2007). Stephen King (Updated ed.). New York, NY: Chelsea.

Boyd, B. (2009). On the origin of stories: Evolution, cognition, and fiction. Cambridge, MA: Belknap Press of Harvard University Press.

Boyer, P. (2001). Religion explained: The evolutionary origins of religious thought. New York, NY: Basic Books.

Carroll, J. (1995). Evolution and literary theory. Columbia, MO: University of Missouri Press.

Carroll, J. (2006). The human revolution and the adaptive function of literature. Philosophy and Literature, 30(1), 33-49. https://doi.org/10.1353/phl.2006.0005

Carroll, J. (2011). Reading human nature: Literary Darwinism in theory and practice. Albany, NY: SUNY Press.

Carroll, J. (2012). The adaptive function of the arts: Alternative evolutionary hypotheses. In C. Gansel \& D. Vanderbeke (Eds.), Telling stories: Literature and evolution (pp. 50-63). Berlin: De Gruyter.

Carroll, J. (2018). Evolutionary literary rheory. In D. Richter (Ed.), Blackwell companion to literary theory (pp. 423-438). Malden, MA: Blackwell.

Carroll, J. (2019). Death in literature. In T. K. Shackelford \& V. Zeigler-Hill (Eds.), Evolutionary perspectives on death (pp. 137-159). New York, NY: Springer.

Carroll, J., Gottschall, J., Johnson, J. A., \& Kruger, D. J. (2012). Graphing Jane Austen: The evolutionary basis of literary meaning. Basingstoke: Palgrave Macmillan.

Clasen, M. (2009). A conversation with Peter Straub. Cemetery Dance, 61, 40-48.

Clasen, M. (2012). Monsters evolve: A biocultural approach to horror stories. Review of General Psychology, 16(2), 222-229. https://doi.org/10.1037/a0027918

Clasen, M. (2017). Why horror seduces. New York, NY: Oxford University Press.

Clasen, M., Kjeldgaard-Christiansen, J., \& Johnson, J. A. (2018). Horror, personality, and threat simulation: A survey on the psychology of scary media. Evolutionary Behavioral Sciences.https://doi.org/10.1037/ebs0000152

601

602

603

604

605

606

607

608

609

610

611

612

613

614

615

616

617

618

619

620

621

622

623

624

625

626

627

628

629

630

631

632

633

634

635

636

637

638 
Cowan, D. E. (2018). America's dark theologian: The religious imagination of Stephen King. New York, NY: New York University Press.

Curry, O. S., Mullins, D. A., \& Whitehouse, H. (2019). Is it good to cooperate? Testing the theory of morality-as-cooperation in 60 societies. Current Anthropology, 60(1), 47-69. https://doi. org $/ 10.1086 / 701478$

Darabont, F. (1994). The Shawshank redemption [motion picture]. Los Angeles, CA: Columbia Pictures.

Dymond, E. J. (2013). From the present to the past: An exploration of family dynamics in Stephen King's Pet Sematary. The Journal of Popular Culture, 46(4), 789-810. https://doi.org/10.1111/ jpcu. 12048

Gottschall, J. (2012). The storytelling animal: How stories make us human. Boston, MA: Houghton Mifflin Harcourt.

Gutiérrez, P. (2017). The quiet screams of the horror blockbuster. Screen Education, 85, 42-49.

Hansen, R. (2017). Stephen King's IT and Dreamcatcher on screen: Hegemonic white masculinity and nostalgia for underdog boyhood. Science Fiction Film \& Television, 10(2), 161-176. https://doi.org/10.3828/sfftv.2017.11

Hart, D., \& Sussman, R. W. (2009). Man the hunted: Primates, predators, and human evolution (Expanded ed.). Boulder, CO: Westview Press.

Hornbeck, E. J. (2016). Who's afraid of the big bad wolf? Domestic violence in The Shining. Feminist Studies, 42(3), 689-719. https://doi.org/10.15767/feministstudies.42.3.0689

Jancovich, M. (1992). Horror. London: Batsford.

Johnson, D. R. (2012). Transportation into a story increases empathy, prosocial behavior, and perceptual bias toward fearful expressions. Personality and Individual Differences, 52(2), 150-155. https://doi.org/10.1016/j.paid.2011.10.005

King, S. (1986). Maximum overdrive [motion picture]. Wilmington, NC: De Laurentiis Entertainment Group.

King, S. (1990). The dark half. London: Hodder \& Stoughton. (Original work published 1989).

King, S. (1996). The importance of being Bachman. In S. King (Ed.), The Bachman books (pp. v-ix). New York, NY: Plume.

King, S. (1999). Carrie. New York, NY: Pocket Books. (Original work published 1974).

King, S. (2010). Afterword. In Full dark, no stars (pp. 365-368). New York, NY: Gallery Books.

King, S. (2011a). Misery. London: Hodder \& Stoughton. (Original work published 1987).

King, S. (2011b). Pet sematary. London: Hodder \& Stoughton. (Original work published 1983).

King, S. (2011c). The shining. London: Hodder \& Stoughton. (Original work published 1977).

King, S. (2012). On writing: A memoir of the craft. London: Hodder \& Stoughton. (Original work published 2000).

King, S. (2017a). It. London: Hodder \& Stoughton. (Original work published 1986).

King, S. (2017b). Stephen King: Tax me, for f@\%\&'s sake! Retrieved from https://www.thedailybeast.com/stephen-king-tax-me-for-fands-sake

Kjeldgaard-Christiansen, J. (2016). Evil origins: A Darwinian genealogy of the popcultural villain. Evolutionary Behavioral Sciences, 10(2), 109-122. https://doi.org/10.1037/ebs0000057

Lant, K. M. (1997). The rape of constant reader: Stephen King's construction of the female reader and violation of the female body in Misery. The Journal of Popular Culture, 30(4), 89-114. https://doi.org/10.1111/j.0022-3840.1997.3004_89.x

Magistrale, T. (2013). Why Stephen King still matters. In C. L. Crow (Ed.), A companion to American Gothic (pp. 353-365). Hoboken, NJ: John Wiley \& Sons, Ltd.

Mar, R. A., \& Oatley, K. (2008). The function of fiction is the abstraction and simulation of social experience. Perspectives on Psychological Science, 3(3), 173-192. https://doi. org/10.1111/j.1745-6924.2008.00073.x

Mario. (2014, October 15). Mario's review of Pet Sematary. Retrieved from https://www. goodreads.com/review/show/1080958015 
Mercer, E. (2019). The difference between world and want: Adulthood and the horrors of history in Stephen King's It. The Journal of Popular Culture, 52(2), 315-329. https://doi.org/10.1111/ jpcu. 12786

Morin, O., Acerbi, A., \& Sobchuk, O. (2019). Why people die in novels: Testing the ordeal simulation hypothesis. Palgrave Communications, 5(1). https://doi.org/10.1057/s41599-019-0267-0

Norden, E. (1988). Playboy interview: Stephen King. In T. Underwood \& C. Miller (Eds.), Bare bones: Conversations on terror with Stephen King (pp. 24-56). New York, NY: Warner Books.

Rogak, L. (2009). Haunted heart: The life and times of Stephen King. London: JR Books.

Smith, G. (2002). The literary equivalent of a Big Mac and fries? Academics, moralists, and the Stephen King phenomenon. The Midwest Quarterly, 43(4), 329-345.

Spignesi, S. J. (1990). The Stephen King quiz book. New York, NY: Signet.

Strengell, H. (2005). Dissecting Stephen King: From the Gothic to literary naturalism. Madison, WI: University of Wisconsin Press.

Tybur, J. M., Lieberman, D., Kurzban, R., \& DeScioli, P. (2013). Disgust: Evolved function and structure. Psychological Review, 120(1), 65-84. https://doi.org/10.1037/a0030778

Watson, A. (2019). Stephen King - earnings 2010-2018. Statista. Retrieved from https://www. statista.com/statistics/321720/steven-king-earnings/ 